\title{
AC 2010-1712: GLOBAL EXPERIENTIAL LEARNING FOR ENGINEERING TECHNOLOGY STUDENTS
}

\section{Janet Dong, University of Cincinnati}

Janet Dong is an assistant professor in the College of Engineering and Applied Science at the University of Cincinnati. She holds a BS degree in Mechanical Engineering and a MS degree in Manufacturing Engineering. She received her Ph.D. in Mechanical Engineering from Columbia University in 2003. Her academic interests include CAD/CAM, manufacturing engineering technology, process planning, control and automation, robotics, engineering education and research, and manufacturing applications in the dental field.

\section{Janak Dave, University of Cincinnati}

Dr. Janak Dave is a professor in School of Dynamic Systems at University of Cincinnati. He received his M.S. and Ph.D. degrees from Missouri University of Science and Technology (Formerly known as University of Missouri, Rolla). He worked in air-compressor industry, before joining the university. He has presented many papers and moderated workshops at national and International conferences, including ASEE and ASME. His areas of interest include product design and development, Computer Aided Engineering and Computational methods. 


\title{
Global and Experiential Learning for Engineering Technology Students
}

\begin{abstract}
Experiential Learning (EL) is a philosophy in which educators purposefully engage learners in direct experience and focused reflection in order to maximize learning, increase knowledge, and develop skills. Based on the famous experiential learning model developed by David A. Kolb ${ }^{[1]}$ there are four stages in a learning process: Concrete experience, reflective observation, abstract conceptualization and active experimentation. This model shows how theory, concrete experience, reflection and active experimentation can be brought together to produce richer learning than any of these elements can on its own. There are many avenues of concrete experience for the students in engineering technology programs at the University of Cincinnati, such as internships or co-ops, service learning courses, study abroad programs, field projects, academic research, etc. This paper will describe how two faculty members in the Mechanical Engineering Technology department in the College of Engineering and Applied Science (CEAS) designed and delivered two avenues of concrete experience. One is a service learning course with entrepreneurship for honors scholars and the other is a study abroad course for all engineering technology students.
\end{abstract}

\section{Introduction}

The University of Cincinnati (UC) is a large urban public institution with students from around the world. It is also classified as a research university by the Carnegie Commission. The city of Cincinnati is home to nine Fortune 500 companies. These businesses have global operations in the areas design, manufacturing, retailing, servicing, distribution, etc. The University of Cincinnati is very active in the global community. Our faculty members are involved in professional activities in more than 105 countries, from archaeologists in Turkey, biologists in Romania, planners in Indonesia, and engineers in Switzerland. The university is truly an international enterprise. To address growing international needs, the university has strengthened the language and culture requirements for the bachelor's degree, along with setting goals for student study abroad and international co-op programs.

To meet these global needs, the University of Cincinnati has an established honors scholar programs and various study abroad programs. The honors program is only available to the best students in the university. The study abroad programs are open to the broader student body. These opportunities allow UC students to easily fit in the global workplace.

\section{Honors Program}

The University of Cincinnati Honors Program ${ }^{[2]}$ is comprised of the top 5\% of the University of Cincinnati students and offers an engaging environment in which students are inspired to learn more, do more, and be more. Students are challenged through honors seminars and experiential learning projects, community engagement, research and novel applications of technologies, and creative arts. 
Honors experiential learning projects are about active learning, exploration, self-discovery and pushing the academic envelope and the imagination of the students. These classes are rigorous and challenge the participants.

All university honors students are strongly encouraged to study abroad. Recent study abroad experiences have taken our students to Argentina, Australia, Brazil, China, Germany, Ghana, India, Japan, Mexico, Nicaragua, Russia, Spain, Turkey, the United Arab Emirates, Uruguay, and more.

The table below shows the current admission requirements for the university honors program.

Table 1. The Current Requirements of University Honors Program

\begin{tabular}{|c|c|c|c|c|}
\hline Requirements & First Year & Second Year & Third Year & Fourth/Fifth Year \\
\hline Courses & $\begin{array}{l}\text { Honors } 110 \mathrm{H} \text { or } 101 \mathrm{H} \\
\text { English } 101 \mathrm{H} \text { and } \\
\text { English } 102 \mathrm{H}-\mathrm{OR}- \\
\text { English } 112 \\
\text { (AP, IB or PSEOP credit } \\
\text { for those courses is } \\
\text { accepted) }\end{array}$ & $\begin{array}{l}\text { English } 289 \mathrm{H}^{*} \\
\text { strongly } \\
\text { recommended } \\
\text { (fulfills an honors } \\
\text { experience) }\end{array}$ & -- & $\begin{array}{l}\text { Interdisciplinary } \\
\text { capstone strongly } \\
\text { recommended }\end{array}$ \\
\hline $\begin{array}{l}\text { Experiences } \\
\text { (Honors Seminars }{ }^{1} \text {, } \\
\text { other courses } \\
\text { approved as } \\
\text { Honors Experiences }{ }^{2} \\
\text { and Experiential } \\
\text { Learning Projects }{ }^{3} \text { ) }\end{array}$ & $\begin{array}{l}\text { None required, but } \\
\text { students may start } \\
\text { completing } \\
\text { experiences }\end{array}$ & $\begin{array}{l}\text { Must have a total of } \\
2 \text { experiences } \\
\text { completed by end of } \\
\text { academic year }\end{array}$ & $\begin{array}{l}\text { Must have a total of } \\
4 \text { experiences } \\
\text { completed by end of } \\
\text { academic year }\end{array}$ & $\begin{array}{l}\text { Must have a total of } \\
6 \text { experiences } \\
\text { completed by } \\
\text { graduation }\end{array}$ \\
\hline E-Portfolio & $\begin{array}{l}\text { Create e-portfolio in } \\
\text { Honors } 110 \mathrm{H}\end{array}$ & $\begin{array}{l}\text { Document } \\
\text { experiences in } \\
\text { e-portfolio }\end{array}$ & $\begin{array}{l}\text { Document } \\
\text { experiences in } \\
\text { e-portfolio }\end{array}$ & $\begin{array}{l}\text { Document } \\
\text { experiences in } \\
\text { e-portfolio } \\
\text { E-portfolio must } \\
\text { include } 6 \text { experiences; } \\
\text { must be approved by } \\
\text { Honors Program to } \\
\text { graduate with Honors }\end{array}$ \\
\hline GPA & $\begin{array}{l}\text { Minimum } 3.2 \\
\text { cumulative university } \\
\text { GPA at end of } \\
\text { academic year }\end{array}$ & $\begin{array}{l}\text { Minimum } 3.4 \\
\text { cumulative university } \\
\text { GPA at end of } \\
\text { academic year }\end{array}$ & $\begin{array}{l}\text { Minimum } 3.4 \\
\text { cumulative university } \\
\text { GPA at end of } \\
\text { academic year }\end{array}$ & $\begin{array}{l}\text { Minimum } 3.4 \\
\text { cumulative university } \\
\text { GPA at graduation }\end{array}$ \\
\hline
\end{tabular}

*Engineering students who take English $101 \mathrm{H}$ and English $102 \mathrm{H}$ to satisfy the English composition requirement may take English $289 \mathrm{H}$ as an SE BoK. Engineering students who take English 112 may take English $289 \mathrm{H}$ to satisfy the English composition requirement. In that case, English $289 \mathrm{H}$ will NOT count as a BoK.

In addition to the university wide honors program, each college in the university may have their own honors program. For the College of Engineering and Applied Science (CEAS), the standards of admission to the honors program are slightly lower than the university-wide requirements but are by invitation only. However, CEAS Honors students are only allowed to take the honors classes offered by CEAS. Students must apply to the CEAS honors program 
before the end of their freshmen year. To apply, students need two quarters at UC/CEAS with a cumulative GPA of 3.4 or more and a recommendation from a college faculty. All students meeting the CEAS honors criteria will be admitted to the college honors program upon application. All CEAS student meeting the university-wide honors criteria are automatically enrolled in CEAS Honors program.

\section{Study Abroad Programs}

The table below provides the list of global study programs available to all students and supported by Institute for Global Studies \& Affaires (IGSA) ${ }^{[3]}$ at the University of Cincinnati. The duration of these programs can vary from short term to year-long studies.

Table 2. List of Global Study Opportunities

\begin{tabular}{|c|c|c|}
\hline Summer & Short Term & Honors Plus \\
\hline Internships \& Co-Op & Exchanges & $\begin{array}{c}\text { University Study Abroad } \\
\text { Consortium }\end{array}$ \\
\hline Post-Baccalaureate & $\begin{array}{c}\text { OH International } \\
\text { Consortium }\end{array}$ & \\
\hline
\end{tabular}

A short description of the two programs follows:

The British Study Program (short term) is to study in Harlaxton, England and additional sites, including Ireland and continental Europe. Courses are in a variety of fields, including Literature, Creative Writing, History, Mathematics, and Technology. The course is a variable credit class. The University Study Abroad Consortium (USAC) ${ }^{[4]}$ has programs in many parts of the world, including Western Europe, Asia, Africa and Latin America. The USAC is a non-profit organization made up of 33 U.S. member universities that has provided quality, affordable study abroad programs for almost 30 years. The University of Cincinnati is a member institution of USAC. USAC students come from member universities in the consortium, as well as from over 700 non-member institutions nationwide.

Students may attend for 1 or 2 semesters, or for the summer session. Interested students can obtain more information from the web link (http://usac.unr.edu/) or contact IGSA ${ }^{[3]}$. The courses are taught in English at sites in England, Malta, Australia, New Zealand, Ireland, Scotland, Thailand, Ghana and Israel. One Language and Culture Study course is a two-week intensive language, culture and travel program in Costa Rica. The pre-requisite to this course is one year of university Spanish study or the equivalent as this course is taught in Spanish and concentrates on speaking fluency.

\section{An Honors Experiential Learning Course}

In Spring Quarter 2007, CEAS offered an honors course, Entrepreneurship through Innovative Interdisciplinary Projects in Technology and Community Service ${ }^{[5,6]}$, which explored the connections between entrepreneurship, technology, and community service. 
The course was structured using interdisciplinary teams, which were formed based on the disciplines and backgrounds of the students. Each team was connected to a local nonprofit agency to identify and provide innovative technological solutions to the problem of the nonprofit agency. The teams assessed the technical and commercial viability of the concepts, selected one to implement into a working solution, and presented this for evaluation by both faculty and the nonprofit leaders. For example, one team redesigned existing shower stalls in nursing homes. This design allowed physically disabled patients access to previously unusable facilities. These designs were generic enough for the nursing home to market to other similar institutions. Some of the non-profit organizations included Junior Achievement, Homeless Shelter, Habitat for Humanity, People Working Collaboratively, etc.

Students were educated in the following areas:

- Training in problem-based learning

- Exploring the connections between entrepreneurship and community service

- Interviewing techniques to understand an organization's mission and needs

- Performing analysis of strengths, weaknesses, opportunities and threats (SWOT) of a wide range of organizations

- Brainstorming ideas for technologies that would meet the findings of the SWOT analysis

- Developing and presenting plans for three to four alternative solutions that meet the needs of the selected organization to faculty and appropriate staff for evaluation

- Researching entrepreneurship, intellectual property, and various funding resources

- Composing and presenting a detailed business plan to faculty and agency leaders

\section{Global Experiential Learning Course}

Global experiences are thoughtful, substantive and clearly demonstrate proficiency in the following four global competencies. A globally aware student:

- Possesses global literacy, including knowledge of geography, history, current world issues and similarities and differences among cultures

- Recognizes the interdependence of world economies, political systems and the environment

- Interacts with individuals from different cultures and expresses a sensitivity, appreciation and respect for the complex range of experiences of diverse peoples.

- Participates in a global society and understands one's role as a global citizen

- Applies current technology and uses local resources to improve the quality of human life

In September 2007, a group of CEAS engineering technology students visited Brazil, Argentina, and Uruguay. In Brazil, they visited the oldest public library in South America ${ }^{[7]}$ (Figure 1)and spent an entire day with a former university faculty from Brazil. Students looked at different architectural periods from $15^{\text {th }}$ through the $21^{\text {st }}$ centuries. They also attended a national championship soccer game ${ }^{[7]}$ in the Maracana stadium (Figure 2) in the Rio de Janeiro. Some 
students visited shantytowns outside Rio de Janeiro. In addition, all students had an opportunity to practice their Portuguese by living in a local hostel and using public transportation.

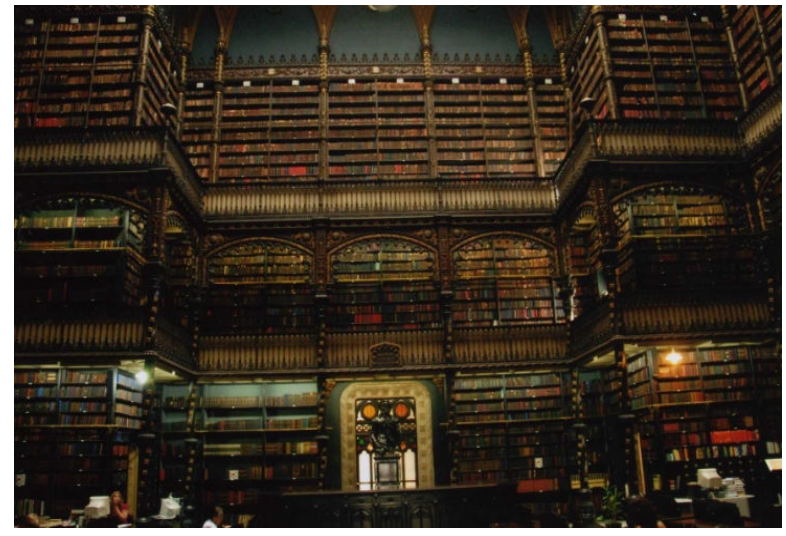

Figure 1. Oldest Public Library in South America

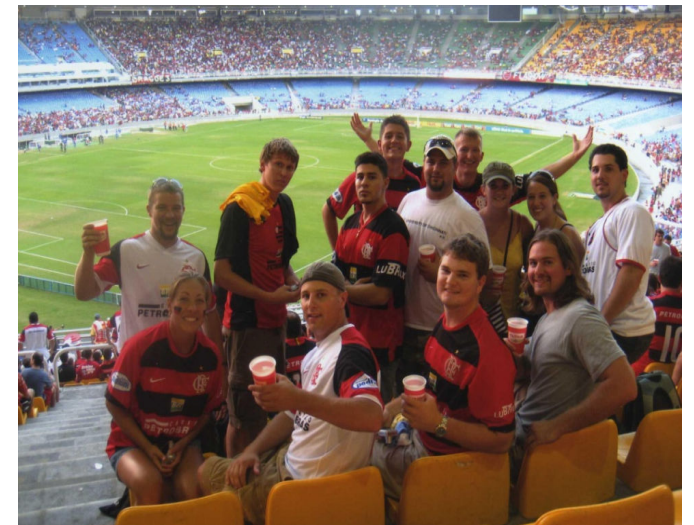

Figure 2. UC Students at Maracana Stadium

In Argentina, students visited La Recoleta cemetery. The Cemetery includes the graves of some of the most influential and important Argentineans, including several presidents, scientists, and wealthy characters. Eva Perón is one of the best-known public figures buried in this cemetery. They also visited a cattle $\operatorname{ranch}^{[7]}$ (Figure 3) and took Tango lessons and practiced their Spanish.

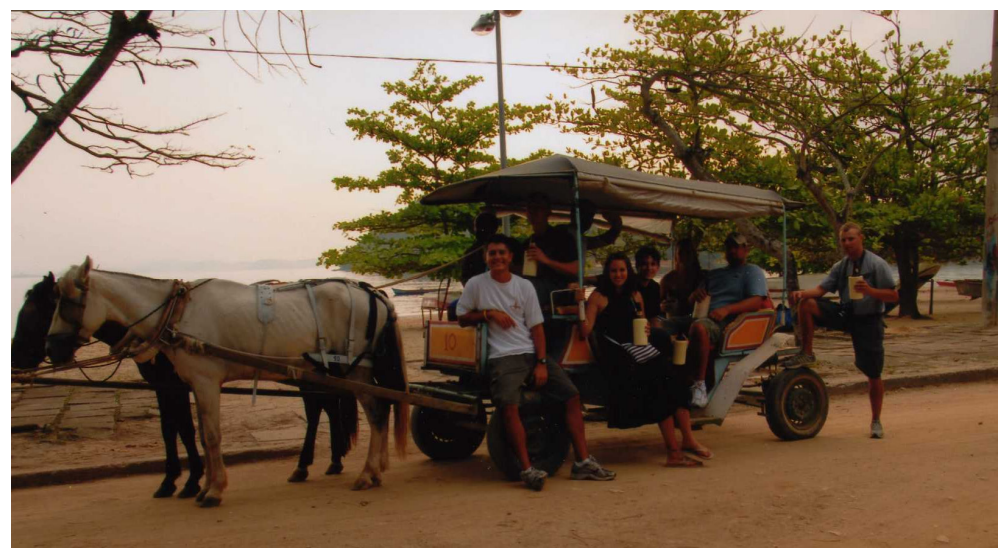

Figure 3. Cattle Ranch in Buenos Aires

The group then boarded a sea ferry to Uruguay, going from Buenos Aires to Colonia, Uruguay. This is a small resort town where the wealthy people from Argentina spend their summers. The students used bicycles and scooters ${ }^{[7]}$ (Figure 4) to get around town. They visited Montevideo, the capital of Uruguay, using inter-city public transportation, a bus. The architectural landmarks and local universities were visited, giving the students the opportunity to talk with local students and exchange information. 


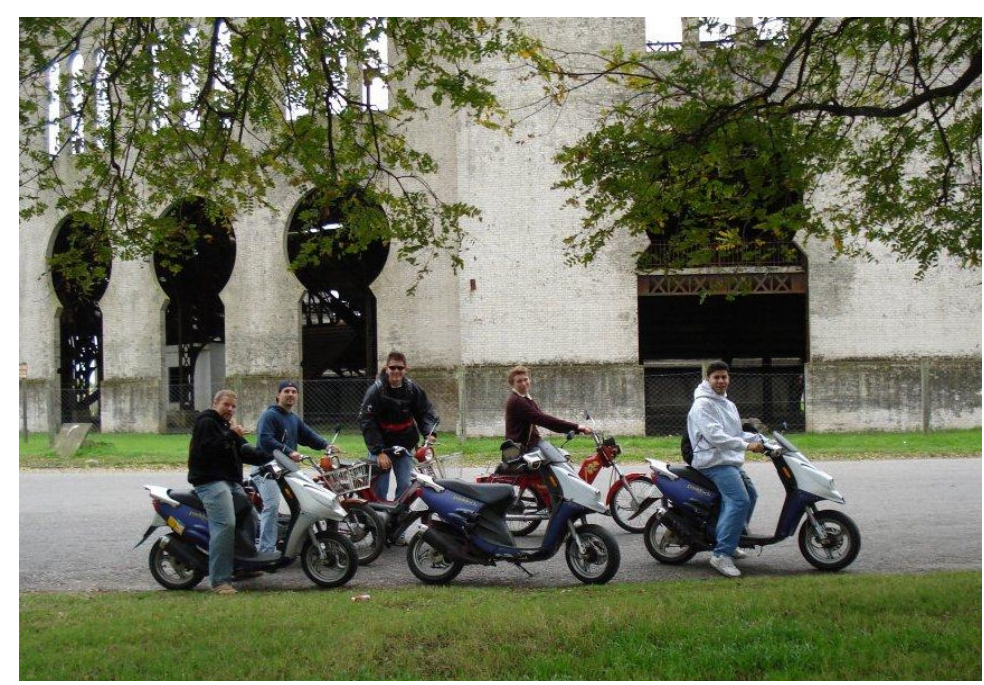

Figure 4. UC Students in Colonia, Uruguay

\section{Outcome and Conclusion}

The University of Cincinnati and the College of Engineering \& Applied Science provides limited resources to honors and study abroad courses. The Honors program provided $\$ 2500$ for the Entrepreneurship Honors Experiential course to support related activities and materials. Through the experiential learning, students were able to transition the selected concept into a workable solution. By partnering with four nonprofit organizations, students generated new applications of existing technology to meet basic human needs. The course also provided the students with realworld business experiences, such as brainstorming, planning, teamwork, and entrepreneurship. The course was intrinsically interdisciplinary and diverse. Students used team-based problemsolving skills. Through its cooperative educational requirement, the college has developed strong ties to the local business community. The abundance of community needs and the partnership with local nonprofit agencies made this course an exceptional opportunity to stimulate students to be innovative and to solve real problems for their community while providing them with the knowledge and skills needed to create and attain leadership and entrepreneurial goals.

All university students are eligible to receive monetary support from the university's International Global Studies and Affairs (IGSA) for study abroad, The amounts can range from $\$ 500$ to $\$ 2,000$ per student. Honor students travelling abroad can receive an additional $\$ 500$ per student. Study abroad allows students to learn about different cultures, histories, culinary arts, architectures, and current technologies in the countries visited. They also had opportunities to strengthen their language and communication skills. These students were required to keep an electronic journal and to submit a visual odyssey of their travels. Some of the visuals from the students' journals are shown in Figures 1 through 4.

While there were individual variations in the assessment of these two courses, students in both were assessed on their teamwork, written and electronic journals, planning, verbal communications, and collaborative use of technologies. Honors experiential learning students were additionally assessed on demonstration of relationships between technology, service, and entrepreneurship. The global experiential learning students were assessed on their language and cultural understanding. Of the forty participants, all but one rated their experiential learning as an 
excellent one. For global experiential learning, the extra cost of travel can be a limiting factor. For the honors experiential learning students, it was the additional time required to communicate with the nonprofit organizations.

\section{Bibliography}

1. David A. Kolb on Experiential Learning, http://www.infed.org/biblio/b-explrn.htm

2. Honors Scholar Program Academic and Curricular Information at the University of Cincinnati, October 2006, http://www.uc.edu/honors/

3. Institute for Global Studies and Affairs, http://www.uc.edu/global/Programs/mprograms.html

4. University Studies Abroad Consortium, http://usac.unr.edu/

5. Honors Special Topics Course Proposal, Entrepreneurship through Innovative Interdisciplinary Projects in Technology and Community Service, George Suckarieh, October, 2006

6. Center for Community Engagement at University of Cincinnati: Connecting the University of Cincinnati and the community through service, October, 2006, http://www.uc.edu/cce/

7. Electronic Journals of Tim Rice and Josiah Brinkerhoff, submitted for the Course of Global Experiential Learning, December 2007 